\title{
BUILDING ENGLISH VOCABULARY THROUGH ROOTS, PREFIXES AND SUFFIXES
}

\section{Metin Yurtbaşı}

\begin{abstract}
Semantics, the study of the meaning of words, is the sum of the basic elements of four skills, namely, reading, writing, speaking and listening effectively. The knowledge of vocabulary words in lexico-semantics, on the other hand, is essential in every grade level, subject area and assessment for every student. In order to improve students' efficiency in the realm of learning and utilizing them in appropriate instances, we must give them means to decode unfamiliar words through such elements called "affixes" and "roots". Based on theories of Constructivism and Bloom's Taxonomy, and in the context of teaching all components of a language and arts curriculum, teaching such common roots and affixes is an effective strategy that would secure them a rich vocabulary. This article will call attention to an alternative dimension to traditional vocabulary teaching based on giving definitions of words or eliciting or deducing meaning from context. According to this methodology, first an awareness is given to students that the English words are essentially borrowings from other languages mostly with Latin or Greek origins (roots) formed by additions to them by parts (affixes) attached to their front and end. So by guessing the meaning of unknown words by such elements, learners are assumed to grasp the idea of the whole word. This article will serve as an introduction to the issue of the nature and functions of word etymology with semantics and lexico-semantics in learning English vocabulary items both for learners and teachers alike.
\end{abstract}

Key words: Semantics, lexico-semantics, affix, prefix, suffix, root. 


\title{
İNGILIZZCE SÖZCÜK DAĞARCIĞININ OLUŞTURULMASINDA KÖKLERDEN, ÖN-EKLERDEN VE SON-EKLERDEN YARARLANMA
}

\begin{abstract}
$\ddot{O} z$
Anlambilim (Semantik) alanı, sözcüklerin anlamlarını inceleyen bir bilimdir. Dil ögrretimindeki dört temel unsurlardan olan "okuma”, “yazma”, “dinleme”, "konuşma" becerilerinin geliştirilmesinde anlambilim verilerinden öncelikle yararlanılır. Anlambilim ’in “sözcük yapısı” alt bölümünde her ögrrencinin kazanması gereken "sözcükleri tanıma” ve "kullanma” beceri düzeyine ilişkin değerlendirmede ulaşılmış olan sözcük bilgisi düzeyi en büyük önemi taşır. Bu yüzden öğrencilerin yeni sözcükler ediniminde, söz konusu sözcüklerin yapılarını oluşturan “ekler" ve "kökleri” tanıması fevkalade başarılı ve etkin bir yöntemdir. "Yapısalcılık ve Bloom'un "Taksonomi” kuramları esas alınarak ve dil ögretimi müfredatı kapsamında ögrencilerin hedef dildeki en yaygın sözcüklerin köklerini, bunların eklerle oluşan türevlerini yani sözcük kökleri ve yapı eklerini ögrrenmeleri, temel sözcük dağarcıklarını geliştirmede uygulanacak en etkili bir strateji olacaktır. Bu yaklaşım geleneksel olarak ögrencilerin metin okuyarak bilinmeyen sözcüklerin anlamlarını "bağlamdan çıkarım” yöntemiyle tahmin etmelerine bir alternatif getirmektedir. Ingilizce ögrencileri, ek ve kökleri ögrenmek suretiyle sözcükleri analiz ederek, önce bunların yapısal bir köke sahip olduklarl ve bu köklerin başlarına ve sonlarına konulan eklerle yeni anlamlı sözcükler oluşturulduğu bilinci kazandırllmaktadır. Daha once tanımadığı sözcüklerin anlamlarını bu kodlarla deşifre ederek çözebilen ögrrenci yeni sözcüğü bilinçli bir şekilde kavrayabilmektedir. Okuyacă̆ınız yazıda, anlambilim ve kökenbilim alanlarının bu konudaki verileri birleştirilerek İngilizce öğrenen ve ögretenlere sözcük dăgarcı̆̆l ediniminde pratik bir yaklaşım sunulmaktadır.
\end{abstract}

Anahtar kelimeler: Anlambilim, sözcükbilim, ekler, ön-ekler, son-ekler, kökler. 


\section{The Importance of Teaching Vocabulary through Roots and Affixes}

An absence of a rich vocabulary greatly prevents English learners from progress and achievement in their ability to understand what they read and hear in the first place. Researcher Wallace stated, "The greatest challenge inhibiting the ability of English-language learners to read is their lack of sufficient vocabulary ". A lack of vocabulary knowledge would extend to an inability to comprehend reading (in any subject), an inability to write at grade level, and an inability to understand the function of words in grammar (Wallace, 2008). The lack of an efficient vocabulary paralyzes students from progressing in their ability to acquire a new language like English for non-natives. The author, Hubbard claims that "the most important barrier to study anthing is the unknown or misunderstood word". He goes on to say that "the only reason a person gives up a study or becomes confused or unable to learn is because he has gone past a word that was misunderstood or not understood correctly" (Hubbard, 1972). Research by Liu and Nation (1985) show that 95\% of the words surrounding an unfamiliar vocabulary word must be known in order for a student to infer meaning of an unknown vocabulary word.

Educators are doing a great disservice to many students if they depend on the student inferring meaning through context clues alone. Even if students advances through grade levels, insufficient vocabulary knowledge can continue to plague them throughout their academic careers, even as they progress in higher education. Researchers Turner and Williams (2007) found that the single best indicator as to a student's success on course examinations was vocabulary knowledge. The case has been made for the importance of teaching vocabulary. Now the next logical step is to investigate the merits of teaching roots and affixes as a method for helping students decode words and deduce meaning based on their knowledge of the word parts. So this very effective strategy to teach English vocabulary through word parts must be meticulously studied and applied. Recognizing and teaching cognates between the two languages, i.e. L1 and L2 could well a starting point for those familiar with them in their mother tongue. Cummins (2002) determined that by using common cognates it is possible to teach English vocabulary to Spanish speakers, nearly 15, 000 words in no time at all. Research by Short and Echevarria (2005) also shows that students who have a Latin-based native language are able to recognize English words with similar Latin derivations. Roots and affixes thus help students decode and decipher the meanings of new words, even if they are in an unknown or unfamiliar language, because they sound and look similar. The knowledge of roots and affixes has been proven to help students of all ages and in a variety of fields of study (Vance, 1991). 
Therefore, as language teachers, we must benefit more in our vocabulary teaching programs in our instruction as early as possible. We must be aware of this important fact that each root word sometimes yields up to a dozen or more English derivatives. If we use this system properly, we can teach thousands of vocabulary in a very short time through prefixes and suffixes and also Latin or a Greek root word through their many derivatives. So it is imperative that we must unlock the latent potential in our students by picking up as many vocabulary items as possible every day in our routine curriculum.

\section{Latin Roots}

We can start giving our students some Latin roots, one of which is the root "docere" [do"ke:re] meaning "to teach" in Latin. No doubt, like other Latin roots, this one also brings several memorable derivatives into English. So let us now start a with few that we and our students may already know, and then move on to those words that are new. After we discover this system of teaching vocabulary through roots we feel that teaching vocabulary has never been so easy! Here are some surprising derivating of this Latin root "docere" (to teach) naming only the first ten: 1 doctor (one who teaches) 2 doctrine (something taught), indoctrinate (to instruct in a certain system or belief) 3 docile (easily taught) 4 indocile (not easily taught or controlled) 4 docility ( the quality of being calm, controlled and teachable) 5 docent (a lecturer, a teacher) 6 docentship (the position held by a docent) 7 Ph.D. (philosophiae doctor - a teacher of philosopy), 8 J.D. (juris doctor - a teacher of law), 9 doctoral (about or concerning a doctor or teacher), 10 doctorate (the degree or status given by a university to those qualified to teach) (Rasinski, 2008)

Starting with this example, in this case, by using a Latin root, we could go on with a few hundred more to generate thousands of new words to instill in our students this tremendous vocabulary learning potential. Then we can go on with Greek roots to teach them some other new vocabulary in such a systematic way. We can thus provide our students with new strategies, ideas, and resources to improve their word treasure including the use of prefixes, suffixes in order to help them improve their comprehension, and ultimately read and speak more effectively. An awareness of Latin and Greek roots also enhance their in-depth understanding of how to incorporate word roots into vocabulary buildup.

By allowing our students at all levels to discover the etymological mystery of words, they will themselves unlock word meanings in a way they have never realized before. They will then themselves expand their command of the language by 
developing a genuine appreciation for words they want to be associated with. This skill will lead them to achieve successful results in their comprehension and expression in their newly acquired language as a whole (Rasinki, 2008).

\section{A listing of the most known Latin roots and their English derivatives:}

The following examples reperesent the commonest Latin roots that students of English encounter in their studies:

\{act\}, \{ag\} (to do, to act) agent, activity; \{apert\} (open) aperture; \{bas\} (low) basement; $\{$ cap $\},\{$ capt $\},\{$ cip $\},\{$ cept $\}$, \{ceive\} (to take, to hold, to seize) captive, receive, capable, recipient; $\{$ ced $\},\{$ cede $\},\{$ ceed $\},\{c e s s\}$ (to go, to give in) precede, access, proceed; \{cred\} (to believe) credible, incredible, credit; \{curr\}, \{curs\}, \{cours\} (to run) current, precursory, recourse, intercourse; $\{$ dic $\},\{$ dict $\}$ (to say) dictionary, indict, indicate; \{duc\}, \{duct\} (to lead) induce, conduct, aqueduct; $\{$ equ $\}$ (equal, even) equality, equanimity; \{fac\}, \{fact\}, \{fic\}, \{fect\}, $\{\mathbf{f y}\}$ (to make, to do) facile, fiction, factory, affect; $\{\mathbf{f e r}\},\{$ ferr $\}$ (to carry, bring) defer, referral; \{mit\}, \{mis\} (to send) admit, missile; \{par\} (equal) parity, disparate; \{plic\} (to fold, to bend, to turn) complicate, implicate; \{pon\}, \{pos\}, \{posit\}, pose\} (to place) component, transpose, compose, deposit; \{scrib\}, \{script\} (to write) describe, transcript, subscription; $\{$ sequ $\},\{$ secu $\}$ (to follow) sequence, sequel, consecutive; $\{$ spec $\},\{$ spect $\},\{$ spic $\}$ (to appear, to look, to see) specimen, aspect; $\{$ sta $\},\{$ stat $\}$, \{sist $\}$ (to stand, or make stand) constant; \{stit\}, \{sisto\} (status) stable, desist; \{tact\} (to touch) contact, tactile; $\{$ ten $\},\{$ tent $\}$, $\{\operatorname{tain}\}$ (to hold) tenable, retentive, maintain; $\{\operatorname{tend}\},\{\operatorname{tens}\}$, \{tent $\}$ (to stretch) extend, tension; $\{$ tract $\}$ (to draw) attract, contract; $\{$ ven $\}$, $\{$ vent $\}$ (to come) convene, advent; $\{$ ver $\},\{$ vert $\},\{$ vers $\}$ (to turn) avert, revert reverse

The point here is that such Latin roots make the nature and composition of words transparent so that the students raise their familiarity and power of analysis to use them in new situations.

\section{Greek Roots}

There are far more words in the English language of Latin origin than of Greek. There are two major reasons for this: first, many words entered the language from French after the Norman conquest in 1066, and French is a direct descendant of Latin. Second, Latin remained the language of science and scholarship in Europe 
throughout the Renaissance and into the eighteenth century, and many words were borrowed directly from Latin, or coined based on Latin and Greek roots. According to one count, approximately $28 \%$ of the English vocabulary comes directly from Latin, and another $28 \%$ from French (most of which is ultimately of Latin origin). Only a little over 5\% is from Greek origin (Prestwick, 2012)

These Greek roots do have mostly one thing in common, they are either related with biology or medicine to separate them from Latin roots forming the English corpus. The oldest written sources of western medicine are the Hippocratic writings from the 5th and 4th centuries $\mathrm{BC}$, which cover all aspects of medicine at that time and contain numerous medical terms. This was the beginning of the Greek era of the language of medicine, which lasted even after the Roman conquest, since the Romans, who had no similar medical tradition, imported Greek medicine. Most of the doctors practising in the Roman Empire were Greek, and the works by Galen of Pergamum, from the 2nd century AD, were for centuries valued as highly as the Hippocratic ones. The Greek legacy comprises numerous names of diseases and symptoms, such as catarrh (downflow), diarrhoea (throughflow), dyspnoea (bad breathing), melancholic (pertaining to black bile) and podagra (a foot trap) (Wulff 2004). So, the Greek roots forming part of today's English vocabulary are related with medicine as opposed to Latin roots related to other technical and scientific fields.

\section{A listing of the most known Greek roots and their English derivatives:} \{acr\} (height, summit, tip) acrobatics, acromegaly, acronym, acrophobia; \{aer\} (air) air, atmosphere, aeronautics, aerosol; \{aesthet\} (feeling, sensation) aesthetics,anaesthetic; $\{\mathbf{a g r}\}$ (field) agronomy; $\{\operatorname{amph}(\mathbf{i})\}$ (around, about, both, on both sides of, both kinds) amphibian, amphibolic, amphoterism; \{andr\} (male, masculine) androgen,android; \{anthrop (human) misanthrope, philanthropy, anthropomorphic; $\{\operatorname{arch}(\mathbf{a})$ e\} (ancient) archaeology, archaic; $\{\operatorname{arche} / \mathbf{i}\}$ (ruler) archangel,archetype; $\{$ bibl\} (book) bible, bibliography; \{cardi\} (relating to the heart) cardiograph, cardiology; \{chrom\} (color) chromium, chromosome, monochrome; \{chron\} (time) anachronism, chronic, chronicle, synchronize, chronometer; $\{$ dem $\}$ (people) democracy, demography, demagogue, endemic, pandemic; \{gastr\} (stomach) gastric, gastroenterology; \{graph\} (write) monograph, graphite; \{morph\} (form) amorphous, metamorphic, morphology; \{organ\} (organ, instrument, tool) organism; \{orth\} (straight) orthodontist, orthodoxy, orthosis; \{path\} (feeling, suffering) empathy, sympathy, apathy, apathetic, 
psychopathic; $\{\operatorname{ped}(\mathbf{o})\}$ (child, children) pediatrician, pedagogue; $\{$ phil(o)\} (having a strong affinity or love) forphilanthropy, philharmonic, philosophy; \{phon\} (sound) polyphonic, cacophony, phonetics

Once again it must be stressed that being familiar with the functions of Greek roots promotes the critical understanding of foreign words in the the structure English vocabulary stock.

\section{Prefixes}

A prefix is a word part placed in front of a base word. A prefix usually changes the meaning of the base word. For instance, the prefix $\{\mathbf{u n}-\}$, an original English suffix opposed to Latin \{in-\}, added to the word happy makes a new word with a new meaning. The prefix \{un-\} means "not," so it changes the meaning of the word happy to not happy.

With $\{\mathbf{u n}-\}$, the other prefix \{re-\} makes he most common prefixes in the English language which appear most frequently and their meanings are easy to understand. $\{$ un- $\}$ means not ( $\{u n\}$ happy $=$ not happy) or the reverse of or opposite of (as in $\{u n\}$ tie), and \{re\} means "again" as in " $\{\mathrm{re}\}$ do" (do again) or back (as in repay)

Prefixes are handy as they never change the spelling of the base word. We simply add the prefix to the beginning of the base word, as in the word $\{u n\}$ willing etc. The spelling of the prefix never changes either. So the prefix is spelled the same no matter what base word it is attached to. For example, if we learn to spell the prefix \{poly-\}, as in poly\}gon, we can depend on poly to be spelled the same in the words polygraph, polyester, and polygram. But we must be aware when double letters occur. For instance, when we add the prefix \{un-\} to natural, both the prefix and the base word retain their original spelling. So the result is $\{u n\}$ natural.

Some similar examples with double letters occurring: $\{$ il $\}+$ logical $=\{$ il $\}$ logical, $\{\mathrm{im}\}+$ mature $=\{\mathrm{im}\}$ mature, $\{\mathrm{il}\}+$ legal $=\{$ il $\}$ legal $\{\mathbf{u n}\}+$ necessary $=\{$ un $\}$ necessary, $\{\mathbf{i m}\}$ migrant, $\{\mathrm{im}\}$ mobile, $\{\mathrm{im}\}$ moral, $\{\mathbf{d i s}\}$ satisfy, $\{$ dis $\}$ service, $\{$ dis $\}$ similar, $\{$ dis $\}$ solve, \{ir\}reconcilable, $\{$ ir $\}$ redeemable, $\{$ ir $\}$ reducible, $\{\mathrm{ir}\}$ regular, $\{$ ir $\}$ relevant, $\{$ ir $\}$ reparable, $\{$ ir\}restistible, $\{$ ir\}responsible, $\{\mathbf{m i s}\}$ spoke, $\{\mathrm{mis}\}$ spell, $\{$ mis\} step. We must also watch out for "prefix look-alikes". As some words contain the same string of letters as a prefix, but upon closer examination we'll find that they are not prefixes. The "re" in "real" is not a prefix. Other examples 
include "uncle", "pretty", “press", “interest", "reach", “irony”, “dish", and "antique" (Vance, 1991).

\section{Adding prefixes to stems}

A prefix is usually added directly to the base word, but sometimes a hyphen is needed. There are six rules for using hyphens with prefixes: 1. We must hyphenate when the prefix comes before a proper noun or a numeral: $\{\boldsymbol{u n}\}$-American, $\{\boldsymbol{p r e}\}$ 1980 2. We must hyphenate when adding the prefix $\{e x\}$ meaning former: $\{\boldsymbol{e x}\}$-president (We must not use a hyphen if $\{\boldsymbol{e x}\}$ means out of or away from, as in $\{\boldsymbol{e x}\}$ pel.) 3. We must hyphenate after the prefix \{self\}: \{self\}-respect, \{self\}-assured, \{self\}control 4. We must hyphenate to separate two a's, two i's, or other letter combinations that might cause misreading or mispronunciation: $\{\boldsymbol{u l t r a}\}$-ambitious, $\{\boldsymbol{a n t i}\}$ intellectual, $\{c o\}$-worker 5. A hyphen may be used to separate two e's or two o's to improve readability or prevent mispronunciation: $\{\boldsymbol{c o}\}$-opt and $\{\boldsymbol{c o}\}$ owner vs. $\{c \boldsymbol{c o}$ ordinate, $\{\boldsymbol{d e}\}$-emphasize vs. $\{\mathbf{r e}\}$ enter 6. We must note that that many words with double e's used to be hyphenated as a general rule, as in $\{\boldsymbol{r e}\}$ elect, $\{\boldsymbol{r e}\}$-establish, and \{pre\}-existing (Rippel, 2012).

However, current style manuals and dictionaries now tend toward "closing" the word except in cases where readability is affected. Both versions are currently accepted and listed in most dictionaries.) A hyphen is sometimes used after the prefix $\{\mathbf{r e}\}$ to prevent misreading or confusion with another word: $\{\boldsymbol{r e}\}$-cover vs. reco$v e r$, as in $\{\mathbf{r e}\}$-cover the boat when you recover from the flu. \{re\}-lay $v$ s. \{re\}lay, as in "Please relay the message that they will re-lay the tiles". While teaching prefixes we must practice adding prefixes to base words to form new words (Ebbers, 2004). While teaching prefixing we must start with a common prefix such as $\{$ re $\}$ and have students add the prefix to simple base words. Words for this activity can be written on index cards or slips of paper. We must be sure to discuss the meanings of the new words. Once students are comfortable with the activity, they can practice combining other prefixes and words: $\{\boldsymbol{r e}\}+d o=r e d o,\{\boldsymbol{r e}\}+$ build $=$ rebuild, $\{\boldsymbol{r} \boldsymbol{e}\}+$ open=reopen, $\{\boldsymbol{r e}\}+$ think=rethink, $\quad\{\boldsymbol{r e}\}+$ fill=refill,$\quad\{\mathbf{r e}\}+$ pay=repay,$\quad\{\mathbf{r e}\}+$ make $=$ remake, $\{\mathbf{r e}\}+$ move $=$ remove, $\{\mathbf{r e}\}+$ place $=$ replace, $\{\mathbf{r e}\}+$ turn $=$ return .

We must create a prefix list, starting with a few examples and have students add to the list as they discover words with prefixes as in the listing below. We must also discuss the meanings of the words on the list as they are added. We must ask our students to look up prefixes in the dictionary and examine the entries near the word. When they look up the word \{hydro-\}, for example, they'll find hydroelectric, 
hydropower, and hydrophobia. The awareness of students at the first stages of their English learning must have great effect on improving their vocabularywhen recognize these items in the new vocabulary they encounter.

\section{A listing of the most known prefixes in English and their uses:}

The following examples are actually windows to the understanding of meaning of vocabulary items:

$\{\mathbf{a}-\},\{\mathbf{a b}-\},\{\mathbf{a b s}-\}$ (away from) absent, abscond; $\{\mathbf{a d}-\},\{\mathbf{a}-\},\{\mathbf{a c}-\},\{\mathbf{a f}-\},\{\mathbf{a g}-\}$, \{an- $\},\{$ ar- $\},\{$ at- $\}$, as- $\}$ (to, toward) adapt, adhere, annex, attract; \{anti- $\}$ (against) antifreeze, antisocial; $\{$ bi- $\},\{$ bis- $\}$ (two) bicycle, biannual, biennial; \{circum-\}, \{cir-\} (around) circumscribe, circle; $\{c o m-\},\{c o n-\},\{c o-\},\{c o l-\}$ (with, together) combine, contact, collect, co-worker; $\{$ de- $\}$ (away from, down, the opposite of) depart, decline; \{dis- $\}$, \{dif-\}, \{di-\} (apart) dislike, dishonest, distant, different; \{epi-\} (upon, on top of) epitaph, epilogue; \{equ-\}, \{equi-\} (equal) equalize, equitable; $\{\mathbf{e x}-\},\{\mathrm{e}-\}$, \{ef-\} (out, from) exit, eject, exhale; $\{$ in- $\}$, \{il- $\}$, $\{$ ir- $\},\{$ im- $\}$, \{en- $\}$ (into) inject, impose; $\{$ in- $\},\{$ ill- $\}$, \{ig- $\},\{$ ir- $\}$, \{im- $\}$ (not) inactive, ignoble, irreversible, irritate; \{inter-\} (between, among) international, interpose; \{mal-\}, \{male-\} (bad, ill, wrong) malpractice, malfunction; \{mis-\} (wrong, badly) mistreat, mistake, misplace; \{mono-\} (one, alone, single) monopoly, monotone, monologue, monosyllable; \{non- $\}$ (not, the reverse of) nonsense, nonprofit; \{ob-\} (in front, against, in front of, in the way of) obstacle, obvious, obviate; \{omni-\} (everywhere, all) omnipresent, omnipotent; \{per-\} (through) pervade, perceive; \{poly- (many) polysyllable, polygon; \{post-\} (after) postpone, postmortem; \{pre-\} (before, earlier than) preview, prehistoric, preface; \{pro-\} (forward, going ahead of, supporting) proceed, promote; \{re-\} (again, back) retell, recall, recede; \{se-\} (apart) secede, seclude; $\{$ sub-\} (under, less than) submarine, subway, subliminal; \{super-\} (over, above, greater) superstar, superimpose; \{trans- $\}$ (across) transcontinental, transverse; $\{$ un- $\}$, \{uni- $\}$ (one) unidirectional, unanimous, unilateral; \{un-\} (not) uninterested, unhelpful, unethical .

It must be noted that in English these prefixes are building blocks of complex and compound-complex words, whose recognition are mostly problem-causing in terms of semantics and pragmatics to Turkish learners of English. 


\section{Suffixes}

Learning suffixes as early as possible during the learning of English is very important for students in that it greatly improves their reading comprehension at all levels. Children and adults alike enjoy learning about suffixes through fun word matching games. Understanding prefixes and suffixes for children is an important part of learning English grammar also. Just as teaching children root words is crucial to improving their general reading comprehension skills, so does learning suffixes, and using suffixes greatly increase children' vocabulary (Onish 2010).

Knowing suffix meanings and suffix definitions also helps students see and use context and etymological clues, allowing them to make educated guesses about the meaning of unfamiliar words. Teaching children basic suffixes early on (even at elementary level) helps to build a strong foundation of speech parts which will be very useful later on when they take graduate and professional school entrance exams especially since there knowledge of suffixes is required in all English exams all the way from elementary to TOEFL and GRE. Therefore an early introduction to this topic is most successful, it should be followed by learning suffixes in middle scho$\mathrm{ol}$ and further reinforced by continuing to study suffixes in high school. As numerous suffixes are derived from Greek and Latin roots, ESL students and teachers can benefit from a multi-lingual approach to the meanings of suffixes (Callella, 2007).

\section{Adding Suffixes to Stems}

Whether learning or teaching suffixes, there are excellent online suffix resources for creating suffix worksheets as well as suffixes activities and suffix lists. Many students of English as a foreign language are not taught that suffixes or word endings will frequently give a clue as to what part of speech a word may belong (e.g., noun, verb, adjective, adverb). Yet, this is a relatively simple way in which to easily recognize what part of speech a word may belong. In fact learners find it extremely useful to learn suffixes by their types, namely Noun Suffixes, Adjective Suffixes, Adverb Suffixes, Verb Suffixes with numerous examples. For instance one can recognize a noun by its suffixes such as $\{-$ ation $\},\{$-acity\}, $\{$-ator $\},\{-$ hood $\},\{-$ ment $\},\{$-or $\},\{$-sion $\},\{$-tude $\},\{$-ure $\}$ by their respectives meanings and examples. As for Adjective Suffixes, such relevant word-endings are used: $\{-$ able $\},\{-f o l d\}$, $\{$-ian\}, \{-ible\}, \{-ing\}, \{-ish\}, \{-ive\}, \{-less\}, \{-ous\}, \{-worthy\}. As for Adverb Suffixes $\{-$ ably $\},\{-$ ibly $\},\{$ ward(s) $\}$ and $\{-$ wise $\}$ are used, and for Verb Endings such suffixes as $\{-$ ate $\},\{-\mathbf{e n}\},\{$-ify $\}$, and $\{-\mathbf{i z e}\}$. These magical codes could teach early learners solid foundation in the morphologicael structure of the thousands of 
new vocabulary to build confidence while acquiring new vocabulary and comprehending texts with great ease.

\section{A listing of the most known suffixes in English and their uses:}

It must be noted that the following suffixes also embody certain morphophological changes the study of which deserves a special research:

\{-able\}, \{-ible\}, \{-ble\} (able to) edible, salable; $\{$-acious\}, \{-cous\}, $\{$-al\} (like, having the quality of) nocturnal, vivacious; $\{$-ance $\},\{$-ancy $\}$ (the act of, a state of being) performance, truancy; $\{$-ant $\},\{$-ent $\},\{$-er $\},\{$-or $\}$ (one who) occupant, respondent, teacher, creator; $\{$-ar $\},\{$-ary $\}$ (connected with, related to) ocular beneficiary; \{-ence $\}$ (quality of, act of) existence; $\{-$ ful $\}$ (full of) fearful; $\{-i c\},\{-$ ac\}, $\{$-il\}, \{-ile\} (of, like, pertaining to) civil, infantile, acidic; \{-ion\} (the act or condition of) correction; $\{$-ism $\}$ (the practice of, support of) patriotism; $\{$-ist $\}$ (one who makes, does) artist; $\{$-ity $\},\{-\mathbf{t y}\},\{-\mathbf{y}\}$ (the state of, character of) unity, shifty, showy; \{-ive\} (having the nature of) active; \{-less (lacking, without) heartless; \{logy (the study of) biology; \{-ment\} (the act of, the state of) retirement; \{-ness\} (the quality of) eagerness; \{-ory\} (having the nature of, a place or, thing for) laboratory; $\{$-ous $\},\{$-ose $\}$ (full of, having) dangerous, verbose; $\{$-ship $\}$ (the art or skill of, the ability to) leadership; \{-some $\}$ (full of, like) troublesome; \{-tude\} (the state of quality of, the ability to) aptitude; $\{-\mathbf{y}\}$ (full of, somewhat, somewhat like) musty, chilly, willowy

\section{Conclusion}

Many researches have shown the benefits of building English vocabulary through a systematic learning of roots and affixes as a start to be followed by supporting examples. One study has shown that a set 82 roots and affixes (all those given in this presentation), namely 27 roots, 32 prefixes and 23 suffixes and the knowledge of how to use them will unlock the meaning of over 100,000 words in English. Grasping these miraculous keys does not only help natives or non-natives alike to build a solid vocabulary to have a lot better command of English comprehension and express oneself more confidently, but it also helps one learn such Latin based languages as Spanish, French, and Italian - or even Greek very quickly. The theoretical basis for an extensive use of this etymological study lies within the educational philosophy of Constructivism, as well as in Benjamin Bloom's work. What 
is commonly known in education sciences as "Bloom's Taxonomy" is a classification of learning objectives within education. It was first proposed in 1956 by a committee of educators chaired by Benjamin Bloom and the project soon turned into a standard text, Taxonomy of educational objectives: the classification of educational goals in which "the educational content knowledge is demonstrated by defining and categorizing relevant processes" (Bloom, 1956).

In the related learning theory so called "Constructivism" the teacher is the facilitator where students are helped construct knowledge or create their own meaning out of information they are exhibited. Students thus learning roots and affixes will construct their own meaning out of words by learning decoding skills. Bloom's taxonomy offered the researcher a basis for formulating the pre and posttests. Teaching roots and affixes is beneficial for students on that line in that it gives students a strategy for decoding the meanings of unknown words. Roots and affixes are often cognates with other words in the "Romance Languages," so it is important for English Learners to learn roots and affixes. Students benefit from the study of roots and affixes while studying all their subjects. Explicit-Direct Instruction is also a teaching strategy which teaches students using clear objectives and breaking a lesson down step-by-step for students (Goeke, 2008). While teaching them these items several games and activities could be employed to foster learning and help motivate students as motivation is a key factor in student success.

\section{References}

Bloom, B. (1956). Taxonomy of Educational Objectives, Boston: Allyn and Bacon

Buddingh, Melissa (2005). The effects of teaching roots and affixes on the vocabulary development of underperforming students, BA, University of California, Davis, CA

Callella, Trisha (2007). The Learning Works: More Prefixes and Suffixes, Grades 4-8: Teaching Vocabulary to Improve Reading Comprehension, Creative Teaching Press

Cummins, J. (2002). Making a difference in the lives of bilingual-bicultural learners.

Ebbers, Susan M. (2004). Vocabulary Through Morphemes: Suffixes, Prefixes, And Roots For Intermediate Grades, CD, Book, \& Reproducibles

Goeke, Jennifer L. (2008). Explicit Instruction: A Framework for Meaningful Direct Teaching, page 11.

Hubbard, L. Ron (1972). Learning How to Learn, p. 101; Basic Study Manual Journal, 16(1), 33-42.75 


\section{Metin Yurtbaşı}

Onish, Liane (2010). Vocabulary Packets: Prefixes \& Suffixes: Ready-to-Go Learning Packets That Teach 50 Key Prefixes and Suffixes and Help Students Unlock the Meaning of Dozens and Dozens of Must-Know Vocabulary Words.

Prestwick House (2012). Vocabulary from Latin and Greek Roots, Prestwick House Clayton, $D E$

Rasinski, Timothy, Nancy Padak, Dr. Rick M. Newton, Evangeline Newton (2008). Greek \& Latin Roots: Keys to Building Vocabulary, Corinne Burton

Rippel, Marie (2012). All About Spelling and All About Reading, Eeagle River, WI

Short, D., \& Echevarria, J. (2005). Teacher skills to support English Language

Turner, H., \& Williams, R. L. (2007). Vocabulary development and perfomance of multiple-choice exams in large entry-level courses. Journal of College Reading and Learning, 37(2), 64-81

Vance, Timothy (1991). Instant Vocabulary through Prefixes and Suffixes, Power Japanese

Wallace, C. (2008). Vocabulary: The key to teaching English language learners to

Wulff, Henrik, MD (2004). The language of medicine, JRSM Med. 2004 April, 97(4). 187-

188 